\title{
PROPOSED REVISIONS IN THE FARM CREDIT SYSTEM: CURRENT LEGISLATION
}

As this country enters the initial stages of a war economy, American agriculture is just emerging from the havoc created by the last World War. Basically its distress has been the result of over-exuberant production in the face of a stable or well-supplied market. ${ }^{1}$ Its problems are nowhere more acute than in the field of agricultural credit. During the first world war cra, farm mortgage indebtedness jumped from $\$ 3,200,000,000$ to $\$ 10,702,000,000.2$ Largely as the result of foreclosures and write-offs, that debt has been reduced by approximately one-third. But even in 1940, 25\% of this reduced debt was either delinquent or had overdue payments extended. ${ }^{3}$ Within a period of seven years, one-eighth of all farms under mortgage to the federal land banks and Farm Mortgage Corporation were repossessed, and in the single year 1939, the system acquired nearly 18,000 farms. ${ }^{5}$ A further indication of the seriousness of the farm credit problem is the rapid growth of farm tenancy. In 1935 approximately half of all farm families were tenants, ${ }^{6}$ and the President's Committee on Farm Tenancy reported that the number was increasing at the rate of 40,000 families a year. These conditions are by-products in part of the unsatisfactory nature of the farm credit system, which has been characterized by overlending in good times, and foreclosures and insecurity in depression periods. ${ }^{8}$ If anything has been demonstrated by the last war and the ensuing period of deflation, it is that traditional credit concepts are insufficient to handle the credit problems of agriculture.

With farm prices and land values again climbing toward inflation levels, re-examination of the credit needs of American agriculture is appropriate. An appraisal is therefore presented of the existing credit system in terms of its past performance and capacity to meet the new strains of a war economy and potential post-war deflation. Its scope includes evaluation of

1. See Yearbook of Agriculture (U. S. Dep't Agric. 1940) 390-96.

2. The figures are for the years 1910 and 1922 respectively. See Torgersin, Aqricultural Finance in the United States (1940) 16 J. Laxb \& P. U. Eco:i. 196.

3. See Hearings before Subcommittee of Committe on Bonling and Currency on S. 3509, 76th Cong., 3d Sess. (1940) 270 (hereafter cited Hearings on S. 3509).

4. See Hearings before Committec on Agriculture on H. R. 8748,76 th Cong., 31 Sess. (1940) 239.

5. (May, 1941) 4 Agric. Fin. Rev., No. 1, tab. S.

6. Of the $6,812,350$ farm families in the United States in $1935,2,865,155$, or $42 \mathrm{r}$, were farm tenants. See Yeareoor of Agriculture (U. S. Dep't Agric. 1940) SSS.

7. Farmi Tenancy, Report of the Presinent's Commitree (1937). For a summary treatment of the farm tenancy problem, see Yeuscook of AGricultune (U. S. Dep't Agric. 1940) 887-906. See generally Farm Tenancy (1937) 4 Law \& Co:merop. PROB. 423-572.

8. See Yearboor of Agriculture (U. S. Dep't Agric. 1940) 752-54. 
the temporizing measures of the depression era and discussion of the possibilities for revision of the long-term credit system. Since governmental agencies are assuming increasing importance in the field of farm credit, ${ }^{0}$ the focus of investigation is on them. A successfully administered governmental program, however, will point the way to the adoption of similar policies by private institutional lenders, ${ }^{10}$ the traditional source of farm credit. While short-term and intermediate-term credits are essential to the orderly functioning of the farm economy, they are here only collaterally relevant. The problems there involved are of a different nature from those of longterm credit. Chiefly they are questions of management and attention to details, rather than normative considerations of the principles upon which the credit system is to operate. ${ }^{11}$ Moreover, existing agencies seem capable of providing adequate short-term credit for the farmer. ${ }^{12}$

\section{Appraisal of the Existing Credit System}

The Mechanics of the Land Bank System. The Federal Farm Loan Act of $1916^{13}$ established a farm credit scheme patterned after the Landschaft system of Germany.14 Its distinguishing features are the requirement that each borrower guarantee the obligation of all other borrowers, ${ }^{16}$ and the provision for obtaining funds by the issuance of bonds, with the collective value of the mortgages as security. ${ }^{16}$ To implement these principles, twelve federal land bank districts have been established, ${ }^{17}$ and prospective borrowers

9. For statistics from 1910 to 1940 on total farm mortgage debt and amounts held by selected lender groups, see 25 The Agricultural Siruation (Bur. of Agric. Econ., U. S. Dep't Agric., May, 1941) 12.

10. See Eighth Annual Report of Farm Credit Administration (1940) 1.

11. See Benner, The Federal Intermediate Credit Srstem (1926); Yearuook of Agriculture (U. S. Dep't Agric. 1940) 751-52.

12. See Erghth Annual Report of the Fardr Credit Administration (1940) 59-99.

13. 39 Stat. 360 (1916), 12 U. S. C. $\$ 641$ (1940). The Act was declared constitutional in Smith v. Kansas City Title \& Trust Company, 255 U. S. 180 (1921). It will hereafter be cited by section number only, except where the original provisions have been significantly amended.

14. In 1913, President Wilsoṇ appointed an American Commission, headed by Senator Duncan U. Fletcher, to investigate and report on cooperative land-mortgage banks, rural credit unions and similar institutions in Europe. SEN. Doc. No. 214, 63d Cong, 1st Sess. (1913) 3. For analysis of the German Landschaft system, see id. at 354-66.

15. In the European system, unlimited liability of borrowers was characteristic. See Wright, Farm Mortgage Financing (1923) 40. The land bank system adopted here limits borrowers' liability to $5 \%$ of their own loan. $\S 9$; 48 STAT. 271 (1933), 12 U. S. C. $\$ 744 a$ (1940). See Knox National Farm Loan Association v. Phillips, 300 U. S. 194 (1937).

16. Section 13 (subd. third). For this aspect of the Landschaft system, see Wuatr, loc. cit. supra note 15.

17. The original federal land bank districts were supplanted in 1937 by twelve farm credit districts with identical boundaries. 50 STAT. 704, 707 (1937), 12 U. S. C. $\$ \S 671$, $640 \mathrm{a}$ (1940). 
are authorized to form National Farm Loan Associations within eacl district to act as intermediaries of the land bank in making loans. ${ }^{16}$ Long-term loans backed by mortgages are made by the land bank through the farm loan associations. ${ }^{19}$ Endorsed by the association as surety, the mortgages are suld to the land bank of the district, ${ }^{20}$ and the bank is empowered to issue bunts with the mortgages as security.21 Great stress is placed upon the cooperative features of the system. Farmer-ownership and control is theoretically to lie achieved by requiring each borrower to subscribe to stock in the farm lisan association in an amount equal to $5 \%$ of the principal of his loan. 2 The association must in turn subscribe to land bank stock in an amount culual to $5 \%$ of the value of its mortgages held by the land bank.23 The stock of borrowers is held by the association to absorb its losses, and stock of the association is held by the land bank to provide a similar contingency fund against association defaults. ${ }^{24}$ This elaborate mechanism was evolved in an effort to create a system which would be responsive to the will of farmerborrowers. It was thought that by placing the borrower in the position of a stockholder and by making him liable not only for his own loan, but for the defaults of his fellow-borrowers, a high degree of interest in the operation of the system would be fostered. ${ }^{25}$

Evaluation of the Existing Credit Systcm. Inadequacies of the land bank system which have become apparent during the past twenty-five years may in part be attributed to the wide variance in agricultural conditions between this country and Europe where the principles of the system were developed. The farm economy of continental Europe is based upon an immobile peasant class operating family-sized farms on a self-sustaining basis. This country, on the other hand, has developed commercialized and mechanized agriculture $^{26}$ with a consequent multiplication of credit needs. ${ }^{2 i}$ And instead of

18. Section 7. As of December 31, 1939, there were 3,722 operating national farm loan associations. See Sevexth Anvual Report of the Farar Cafont AprimismaTioN (1939) 31-32.

19. Sections 9, 12, 13 (subd. sciond).

20. Section 11 (subds. first, sccond).

21. Section 13 (subds. first, third).

22. Section 8 .

23. Section 7.

24. Sections 7, 8 .

25. See 53 Cong. REc 453-55 (1916). Even at the time the original bill was passed, grave doubts of the wisdom of the stock subscription requirement were expressed in Congress. See Hearings before Committec on Alpriculture on H. R. 8748, 76th Cong," 3d Sess. (1940) 248-49.

26. Commercialization and specialization have been the necessary compliments in agriculture to the factory system and mass production in industry. For a discussion of the influence of technical progress on agricultural production, see Yeancoon of AGstculture (U. S. Dep't Agric. 1940) 509-32.

27. In 1900 the average farming operation might have been undertaken with an investment of $\$ 3,000$; in 1930 the amount of capital required for this purpose was about $\$ 8,000$. See id. at 743 . 
operating under the reasonably stable weather and price conditions prevailing in Europe, agriculture in the United States has been exposed to cyclical changes in weather ${ }^{28}$ and drastic fluctuations in prices. ${ }^{20}$ These factors have placed strains upon the credit structure which it was not designed to bear.

One of the principal specific weaknesses of the system results from the concentration of the burden of losses on too small a group. ${ }^{30}$ The national farm loan associations which attempt to absorb their losses by charging them off against the stock subscriptions of their member-borrowers break down in a period of agricultural stress. In 1940, the capital of $60 \%$ of the associations was so badly impaired through losses that they could not make new loans. ${ }^{31}$ Of the associations organized since $1933,20 \%$ liave suffered such severe losses that they are no longer able to function. ${ }^{32}$ In the St. Paul district, the area most affected by the drought, $81.8 \%$ of the associations can no longer make loans. ${ }^{33}$ But this condition is not confined to disaster areas. The percentage is even higher in the comparatively favorable area serviced by the Baltimore bank, and nearly as high in the New Orleans district. ${ }^{34}$ Attempts to alleviate the situation by the use of compartments within an insolvent association, ${ }^{35}$ through which new borrower's may secure loans without becoming liable for losses previously incurred by the association, have been of doubtful value. The interest rate on stuch loatus is one-fourth of one percent higher than the usual rate, ${ }^{30}$ and even with

28. An exhaustive study of climate and agriculture is contained in the YEARBOOK of Agriculture (U. S. Dep't Agric. 1941). See particularly id. at 685-99. See also Hcarings beforc Committee on Agriculture on H. R. 8748, 76th Cong., 3d Sess. (1940) 249.

29. See Yearbook of Agriculture (U. S. Dep't Agric. 1940) 386; Handeook or Economic Information on the USE of Farm Credit (U. S. Farm Credit Adm'n) 3. For an analysis of current price tendencies, see 25 The Agriculrural Situntion (Bur. of Agric. Econ., U. S. Dep't Agric., July, 1941) 9-12; 25 The Agricultural Sirustion (Bur. of Agric. Econ., U. S. Dep't Agric., Oct., 1941) 5-8.

30. This fact was emphasized by the Secretary of Agrictulture in his testimony on the Farm Credit Act of 1940. Hearings. on S. 3509, 76th Cong., 3d Sess. (1040) 271-74.

31. See id. at 9. For more specific statistics, see Hearings before Commiltec on Agriculture on H. R. 8748, 76th Cong., 3d Sess. (1940) 18.

32. Statistics are for the year 1940. See Hearings on S. 3509, 76th Cong., 3d Sess. (1940) 272.

33. See ibid.

34. $85.7 \%$ of the associations in the Baltimore district were so badly inulaired in 1940 that they could not make loans, and in the New Orleans district the percentage was 66.4. See ibid.

35. This expedient was adopted in the Farm Credit Act of 1937. Loans arc made directly to the borrower by the land bank until there are at least ten such borrowers with loans aggregating not less than $\$ 20,000$. A compartment in the farm loan associntion is then formed for the new borrowers. 50 STAT. 711 (1937), 12 U. S. C. $\$ 724$ (1940). Approximately 860 such compartments have been organized. Hearings on S. 3509, 76th Cong., 3d Sess. (1940) 205.

36. This rate is still one-fourth of one percent less than that on direct loans made by the land banks. 48 Stat. 44 (1933), 12 U. S. C. $\$ 723$ (b) (1940); 50 StAT. 711 (1937), 12 U. S. C. $\S 724(1940)$. 
this expedient, $35 \%$ of the associations are unable to operate. ${ }^{37}$ Morcover, since the associations hold stock in the land bank, banks have been reluctant to shift resources to bolster the weaker associations for fear that the action would be held a preferential dividend. ${ }^{3 s}$ With each unit of the system thus left to absorb its own losses, the resistance of the organization as a whole is undermined.

Another developmental imperfection in the present credit structure is its failure to function as a cooperative system. The stock subscription requirement, which was designed to stimulate interest of borrowers in the organization and insure farmer-ownership and control, has operated only as an additional commission for the loan. Losses are so severe in many cases that they consume the entire value of the stock. Instead of getting dividends, the borrower pays interest on his shares, since they are normally bought with part of the proceeds of his loan. The stock is in fact a liability rather than an asset, a condition which is reflected in the disinterest of borrowers in stockholder activities. Only 18\% of the borrowers attend stockholder meetings, ${ }^{39}$ and 20 to $30 \%$ of the stock originally accumpanying the loans is now held by outsiders. ${ }^{40}$ The typical attitude of the borrower, once he has obtained his loan, is one of indifference to the operation of the system until his obligation matures. And not only inclinations but also opportunities for control are limited. The borrower elects none of the directors of the land bank of the district. He has power to vote only for directors of the local farm loan association, $\$ 1$ who in turn elect one of seven directors of the land bank. ${ }^{22}$ And this indirect method of control is further attenuated by the requirement that salaries paid to association directors be first approved by the Farm Credit Administration. ${ }^{43}$ In practice stockholder-luvrowers also have little power over the important functional controls in the credit system.

37. See Hcarings on S. 3509, 76th Cong., 3d Sess. (1940) 205, 272.

38. Generally stockholders are entitled to participate equally in the distributiun oi nct profits, unless otherwise provided by the terms of their contract with the corponation. See Note (1928) 55 A. L. R. 65.

39. Recently efforts have been made to increase stockholder-burrower participation by publicity campaigns and inducenents to attend stoelsholder neetings, but there has been no marked increase in interest. See Hiarings on S. 3509, 76th Cung., 3d Sess. (1940) $167-68$.

40. This has resuited from transfers or sales of the pruperty where the purchaser has refused to take the stock or refused to pay anything for it. See id. at 10 . In the Federal Farm Loan Act, it is specifically stated that no persons except horrowers on farm land mortgages shall be members or shareholders of national farm loan associations. $\$ \&$.

41. Section 7 as amended, 50 Strit. 710 (1937), 12 U. S. C. $\$ 712(1940)$.

42. 50 StAT. 704 (1937), 12 U. S. C. $\$ 640(\mathrm{~b})$ (1940). The asseciations of the district also nominate candidates for a district director, and from the thrce highest nominees the Governor of the Farm Credit Administration appoints one as district director. Ibid., 12 U. S. C. at $\$ 640$ (d).

43. Section 7 as amended by Exec. Okwer Nu. bust (March 27, 1933), 12 U. S. C. $\$ 713(1940)$. 
Ultimate authority on loan values rests with the land bank appraiser, ${ }^{44}$ and discretion in regard to foreclosure and lending policies is vested in the board of directors of the land bank, ${ }^{45}$ despite the fact that losses on foreclosures and write-offs must be borne by the farm loan associations and their borrowers.

A further defect in the present credit structure arises out of the anmual Government subsidy required to maintain a reasonably low rate of interest on loans. The Federal Farm Loan Act established as the minimum rate on loans the interest rate in the last series of farm loan bonds issucd by the land bank prior to making the loan, plus one percent for administrative expenses and losses. ${ }^{46}$ Rates on loans have varied between $4 \%$ and $5 \%$, depending on the amount of interest required of the land banks on their bonds. ${ }^{47}$ Thus, to enable the banks to provide an effective rate of $3 \mathrm{y} / 2 \%$ to the borrower, annual interest subsidies to the land banks of approximately $\$ 36,500,000$ have been needed.48 Between 1933 and 1940, the United States Treasury paid a total of $\$ 196,274,421$ to the land banks for this purpose. ${ }^{40}$ Yet an even larger subsidy would have been required had not the Government, by an indirect guarantee of land bank bonds, enabled the banks to obtain funds at lower interest costs. Investors have purchased the bonds at lower rates in reliance on continuing Government support of the land bank credit structure. The Federal Farm Mortgage Corporation has been author-

44. Each farm loan association has a loan committec which investigates the character and solvency of loan applicants and the sufficiency of the security, but no loan may be made without favorable report by the land bank appraiser. $\$ 10$ as amended, 41 STsT. 570 (1920), 12 U. S. C. $\$ \$ 751-53$ (1940).

45. Section 13 as amended by 47 STar. 14,1548 (1933), 12 U. S. C. $\$ 781$. Sce Federal Land Bank of New Orleans v. Lee, 174 Miss. 774, 165 So. 613 (1936); Federal Land Bank of Omaha v. Wilmarth, 218 Iowa 339, 252 N. W. 507 (1934). It las frequently been alleged that bondholder committees are an influential factor in determining land bank credit policies. See Hearings on S. 3509, 76th Cong., 3d Sess. (1940) 171.

46. Section 12 (subds. second, third). The maximum rate was set at $6 \%$, exclusive of amortization payments. See ibid.

47. The interest rate written in the mortgage contract for new loans made through unimpaired national farm loan associations in 1940 was $4 \%$; the rate through associations whose stock had become impaired was $4 \frac{1}{4} \%$; for loans made directly by the banks it was $41 / 2 \%$. See Eighth ANnusi Report of Farm Credit Administuntion (1940) 24. Loans by the Land Bank Commissioner are written to bear interest at the rate of $5 \%$ a year. See $i d$. at 52 .

48. See Hearings on S.3509, 76th Cong., 3d Sess. (1940) 13. The Emergency Farm Mortgage Act provided that for a five-year period beginning July 11, 1933, the rate of interest charged borrowers should be reduced to $4 \frac{1}{2} \%$. 48 STAT. 43 (1933), 12 U. S. C. $\$ 771$ (1940). In 1935 this rate was reduced to $3 \frac{1}{2} \%$ for a onc-year period, but it hats been extended until July 1942. 49 Stat. 314 (1935), 54 Stat. 684 (1940), 12 U. S. C. $\$ 771$ (subd. tzelfth) (1940).

49. See Eighth Annual Report of Farm Credit Auministration (1940) app., tab. 22. 
ized to purchase the bonds, 50 and the Treasury has been empowered to malie up land bank deficiencies. ${ }^{51}$ This arrangement does not, however, produce the low rate of interest which would come from an outright guarantee of the bonds. And the lower rates resulting from subsidies have been achieved only at great public expense.

Perhaps the definitive flaw in the present credit system grows ont of its appraisal and lending policy. By the terms of the Federal Farm Loan Act loans are to be made up to $50 \%$ of the value of the land mortgaged and $20 \%$ of the value of the permanent insured improvements thereon. value of the land for agricultural purposes is the basis of appraisal, and the earning power of the farm is a principal factor. ${ }^{\text {ss }}$ In practice, however, this standard has been tortured to include factors totally unrelated to the earning power of the farm. As "things which must be considered," the present appraisal manual cites the earning power of the farm based on representative management and normal prices for farm products; its home desirability; the various other factors which affect farm value such as type of farming, adaptability to diversification, location, hazards involved, the agricultural development of the area, and general desirability of the property; and normal agricultural value, present market value, normal market value, recovery value, commercial or special purpose value, speculative value, and prudent investment value. 54

The standard is so complex as to be no standard at all, and in actual practice its effect has been to focus the attention of both lender and borrower upon the market value or per acre value of the farm as collateral security for the loan. The weaknesses of this approach have become increasingly apparent. It subjects the lending scheme to a variety of inflationary and deflationary forces which inure to the detriment of both borrower and lender. In a period of rising prices for farm products and farm real estate, overlending is the normal result. ${ }^{\text {t5 }}$ During periods of low prices, when farm

50. The land banks were authorized in 1933 to issue up to $\$ 2,000,000,000$ of Government-guaranteed bonds for purposes of making new loans, or for purchasing mortgages. 48 Stat. 41 (1933), 12 U. S. C. \$992 (1940). When the Federal Farm Mrortgage Corporation was formed, it was given power to purchase farm loan bonds, and authority to issue guaranteed obligations was transferred to it. 48 SrAT. $345,346,12$ L. S. C. $\$ \$ 9923$, $1020 \mathrm{c}(1940)$.

51. Government subscriptions to the paid-in surplus of the land banks equal to the amount of the extensions and deferments granted by the banks were authorized in 1933 . 48 Stat. 43 (1933), 12 U. S. C. $\$ 781$ (subd. tenth) (1940). Subseriptions to paid-in surplus by the Secretary of the Treasury from 1933 to 1940 totaled $\$ 114,27+4,421$. See Eighth Anvual Report of Farm Crentr Anarivistratiun (1940) app., tals. 23.

52. Section 12 (subd. $f f f h$ ).

53. Ibid.

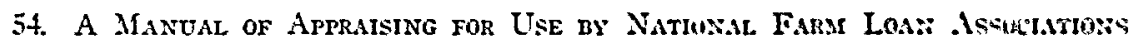
(Land Bank Div., Farm Credit Adm'n, 1940) 1-25.

55. The sequence of events is graphically traced in the Huspeos of Ecosmsste Information on the Use of Farm Credit (U. S. Farm Credit Adm'n) 2, 3. 
income drops, the debt burden becomes unbearable. ${ }^{68}$ Thus, in the early thirties farm values dropped one-half and farm income two-thirds, but the mortgage debt remained practically constant. ${ }^{57}$ As a result, interest charges consumed approximately $35 \%$ of cash income of mortgaged farms, forced sales or foreclosures averaged $39.4 \%$ of all farm transfers, ${ }^{68}$ and widespreatl refinancing and reamortization of mortgages became a necessity. The plain fact is that valuation of the farm as collateral security is a concept foreign to the purposes of the loan. The farmer does not borrow on the assumption that his farm will subsequently be sold to repay the loan. He borrows on the theory that he will repay the loan from the proceeds of his farming operations, and if the loan is to be repaid from these proceeds, clearly its amount should be governed by the earning capacity of the farm. This earning capacity can best be determined by an examination of potential farm income. To determine the loan value of the farm by reference to its sale value, per acre value, or replacement cost of improvements is to insinuate irrelevant criteria into the analysis. These indices may not reflect the value of the farm as a producing agricultural unit, and loans based upon values so established may be similarly out of line with the debt-carrying capacity of the farm. ${ }^{60}$

\section{Temporizing Credit Measures of the Depression Era}

Deficiencies in the long-term credit system have been accentuated by the past decade of deflation, but fundamentally they are not exclusively at depression phenomenon. Credit problems are as much the result of years of agricultural prosperity and expansion as of the ensuing economic stagnation, and any solution of the problems must involve planning to encompass a variety of agricultural conditions. With but few exceptions, ${ }^{60}$ such long-

56. See ibid. The ratio of mortgage debt to value of land and buildings an 1,270,000 full-owner-operated farms was $29.1 \%$ in $1920,39.6 \%$ in 1930 , and $50.2 \%$ in 1935 . Sec Miscellaneous Publication No. 268 (U. S. Dep't Agric. Sept. 1938) 8. Sec Torgerson, loc. cit. supra note 2.

57. See Hearings on S. 3509, 76th Cong., 3d Sess. (1940) 156. See also Handuook of Economic Information on Use of Farm Credit (U. S. Farm Credit Adm'n) 3.

58. See Hearings on S. 3509, 76th Cong., 3d Sess. (1940) 158. Data from Circular No. 354 (U. S. Dep't Agric., April, 1935).

59. Prices bid by outside investors may be the result of hedging against inflation, or because the farm is near a developing suburban area, or for any number of reasons unrelated to debt-carrying capacity of the farm. Land which in a half-century jumps from a free homestead to a farm saleable at $\$ 250$ an acre suggests a speculator's paradise. See Yearbook of Agriculture (U. S. Dep't Agric. 1940) 891.

60. The Farm Credit Act of 1933 established the production credit corporations and production credit associations as a permanent source of short-term credit for agriculture; twelve district banks for cooperatives were also organized under the terms of this Act. 48 Stat. 257 (1933), 12 U. S. C. $\$ \S 1131-31$ h, 1134-34m (1940). For a summary of the long-term rehabilitation work now being carried on by the Farm Security Administration, see Report of thi Administrator of the Farm Security Auministration (U. S. Dep't Agric. 1940) 1-24. 
term planning has been lacking in recent credit legislation. Measures adopted during the depression era were designed primarily to cushion the shock of deflation on borrowers, rather than to provide a permanently satisfactory credit structure. ${ }^{01}$ The legislation proceeded along two somewhat different lines: some measures were aimed at providing outright financial subsidies for the farm debtor, others at liberalizing bankruptcy and moratorium laws.

Financial Subsidies for Farm Debtors. To support the farm credit structure Congress annually appropriated funds for interest subsidies to the land banks, and contributed $\$ 196,274,421$ to paid-in surplus of the system to enable the banks to grant extensions on interest payments and deferments of principal payments to worthy borrowers. ${ }^{62}$ In 1933, the Farm Credit Administration was organized, and through the eleven credit agencies within its surveillance $\$ 350,000,000$ in subsidies to farmer-borrowers and creditors were dispersed..$^{63}$ In the same year the Reconstruction Finance Corporation was authorized to make $\$ 200,000,000$ available to the Land Bank Commissioner for emergency loans, ${ }^{04}$ and Congress later established the Federal Farm Mortgage Corporation with authority to issue Government-guaranteed bonds up to $\$ 2,000,000,000$ to secure funds for these emergency mortgage loans. ${ }^{65}$

Much of this emergency legislation was for purposes of refinancing. The principal beneficiaries were life insurance companies, who were bailed out

61. The creation and activities of federal credit agencies are discussed in Yearsoon CF Agriculture (U. S. Dep't Agric. 1940) 745-49. Federal refinancing of mortgage loans during the depression is analyzed in Woonntrf, Farar Mfortenge Lon:ss of Liff Insuraxice CoMpantes (1937) 13\&-56. Data on emergency mortgage loans made by

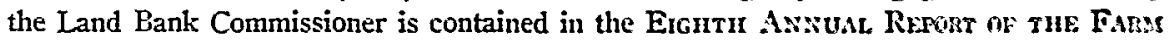
Cremit Adarnustration (1940) 51-58.

62. See Eightir Axwual Report of tire Farm Crenit . Idministrition (1940) app., tab. 22. The land banks have adopted a number of other palliatives to relieve the strain on borrowers. If the delinquency is only temporary, the bank may simply fortear cullection or grant a formal extension of the delinquent item; reamortizations of loans are also being effected, and where the borrower is indebted to both the land bank and the mortgage corporation, the latter may agree to make no demand for principal or interest for a period of five years. Under a lease-option arrangement adupted by some of the land banks, former owners are allowed to lease ana repurchase their farms. This procedure, however, is not mandatory, and in 1940 only (if') farms were thus sold by the Federal Farm Mrortgage Corporation to former owners. See id. at 54-58; Hearings on S. 3509, 76th Cong., 3d Sess. (1940) 207-10.

63. See Corey, $A$ Straight Lane to Socialism (Iune, 1940) 28 N.truus:s Bustrass 15, 17. For a summary of these organizations and their function, see 1 C. C. H. 1941 Fed. Admin. Proc. at p. 13145.

64. These loans were not to exceed $\$ 7,500$ to any one farmer, or $75 \%$ of the $n u r-$ mal or prudent investment value of the farm property. 48 Sr.iT. $48(1933)$ as amtuded, 48 STAT. 347 (1934), 12 U. S. C. \$1016(b) (194(1).

65. 48 Stat. 345 (1933), 12 U. S. C. $\$ 1020$ (1940). The nutes and martgages which had already been taken by the Commission were, by the Federal Farm Murtgage Act, expressly transferred to the Corporation. Iloid., 12 U. S. C. at $\$ 1020 b$. 
to the estimated extent of $\$ 265,000,000$ between May 1933 and January 1936. ${ }^{66}$ Although these financial subsidies were helpful in ameliorating the severity of the crisis, they served at the same time to postpone a frontal attack on the basic problem of establishing a permanently satisfactory credit system.

Farm Bankruptcy Legislation. Further to ease the strain on overburdened borrowers, legislation designed to expand the scope of the bankruptcy laws was adopted in the 1933-35 period. ${ }^{67}$ The 1933 attempt, ${ }^{08}$ calculated to facilitate extensions and compositions of farmer indebtedness, proved ineffectual, for success of the proposals depended upon the consent of a majority of creditors holding a majority of claims, thereby giving the first mortgagee an absolute veto over the readjustments. ${ }^{60}$ The coercive effect of Section $75(\mathrm{~s}),{ }^{70}$ added in 1934, was sufficient to bring about many voluntary compositions, but was declared unconstitutional by the Supreme Court. ${ }^{71}$ In 1935, Section $75(\mathrm{~s})$ was reenacted in altered form ${ }^{72}$ and subsequently declared constitutional..$^{73}$ The only real effect of the new procedure, however, is to give the borrower a three-year moratorium. At the end of that period he stands to lose his farm unless he can refinance himself in the interim. ${ }^{74}$

Adoption of more liberal bankruptcy laws is at best a temporizing gesture. Numerically, the class of debtors who can use the laws to good effect is not significant. From 1934 to 1939, the average number of cases concluded under 155.

66. See Woodruff, Farar Mortgage Lonns of Life Insurance Cominnies (1937)

67. See Hanna, Agricultural Compositions and Extensions Under the Bankruptcy Act (1934) 20 A. B. A. J. 9; Hanna, Neze Frasier-Lemke Act (1936) 1 Mo. L. Rev. 1; Roberts, Property, Mortgaged Land and the Frasier-Lemke Act (1935) 13 N. C. L. Rev. 291; Wood and Ackerson, Federal Farm Credit and Bankruptcy Lazes of 1934 (1935) 21 A. B. A. J. 79 ; Comments, Constitutionality of the Frasier-Lemlie Act (1935) 44 Yat.:

L. J. 651, Judicial Barriers to Farm Debt Relief (1939) 48 YALE L. J. 859.

68. Section 75 of the National Bankruptcy Act, 47 Stat. 1470 (1933), 11 U. S. C. $\S 203(1940)$.

69. See authorities cited supra note 67, and Garrison, The Nez Banterupley Amendments: Some Problems of Construction (1933) \& Wis. L. Rev. 291.

70. 48 STAT. 1289 (1934).

71. Louisville Joint Stock Land Bank v. Radford, 295 U. S. 555 (1935), 35 Col. L. REv. 1136.

72. 49 Stat. $943-45$ (1935), 11 U. S. C. \$203(s) (1940).

73. Wright v. Vinton Branch of Mountain Trust Bank, 300 U. S. 440 (1937), 37 Col. L. Rev. 1005, 32 ILl. L. Rev. 239.

74. Prior to the decision of the Supreme Court in John Hancock Mitutual Life Insurance Company v. Bartels, 308 U. S. 180 (1939), petitions under Section 75(s) were often dismissed at the commencement of proceedings on the ground that the debtor had no reasonable hope for rehabilitation within the three-year stay allowed under the section. For a collection of these cases see Wright v. Vinton Branch of Mountain Trust Bank, 300 U. S. 440, 462, 463 (1937). The Bartels case held that it was error to dismiss a debtor's petition on such grounds. However, the practical difficulties of refinancing within three years are still present. See Steinbergh, The Frasicr-Lemke Decision (1937) 13 J. LAND. \& P. U. ECon. 208. 
Section 75 without a declaration of bankruptcy was less than $3300,{ }^{75}$ and in 1938-39 only slightly more than 200 cases were disposed of under Section $75(\mathrm{~s}) .{ }^{76}$ When contrasted with the two and a third millions of farms under mortgage, ${ }^{77}$ the limited degree to which these bankruptcy laws are used is readily apparent. Some increase in their use may be anticipated from the decision in Hright v. Union Central Life Insurance Company" in which the mortgagor won the right under Section $75(\mathrm{~s})$ to redeem his farm at its appraised value before a creditor could force a public sale. IThile thidecision makes possible an effective procedure for scaling down mortgage indebtedness, Section 75 nevertheless remains subject to two wealinesses shared by all such bankruptcy laws: faulty appraisal methods ma: prevent the necessary deflation of mortgage indebtedness, and adequate measures for refinancing of the debtor are lacking. ${ }^{79}$ Because of these weaknesses, farmers at the end of their moratorium respite remain unalle to take advantage of the opportunity to repurchase or to shake off the burden of inflated indebtedness. Frequently, moreover, efforts to collect sufficient funds fur repurchase result in overproduction and depletion of soil, so that the crelitor loses in the bargain.

\section{Posstbilities for Revision of the Long-Terar Credit Systras}

Appraisal and Lending Policics. Fundamentals of a satisfactory credit system are correct appraisal methods and lending policies. The two are mutually dependent, for errors in one may weaken the effectiveness of the other. Thus, the existing conservative policy of lending only up to $50 q^{\circ}$ of the value of the farm and $20 \%$ of the value of the permanent insureal improvements has frequently been counteracted by errors of appraisal. If

75. See Statistics from REP. ATT'Y GEN. (1934-39). The number of cases by years is as follows: $1934-349 ; 1935-5962 ; 1936-5255 ; 1937-265 ; 1938-2715 ; 1939-$ 2649. For further evidence of the limited use by farm debtors of Section 75 of the Bantruptcy Act, see Hanna, supra note 67, $1 \mathrm{MO}$. L. Rev. at 18; Comment, A Sturicy of Sections 74 and 75 of the Bankruitcy Act in -Actual Operation (1934) 43 Y.uLE L. J. 1235.

76. See ReP. ATr'y GeN. (1938-39) tah. 3C. In 10,35. 124 eases were dispigen of under this section; in 1939, 103 cases were so handled.

77. See The World Alarasac (1941) 604.

7S. 311 U. S. 273 (1940), (1941) 35 ILL L. Rex. 878, \& U af Cnt. L. RN. 539. The case involved the petition of a secured creditur, filed pursuant to the second provion of Section 75(s)(3), asking for an immediate sale and alleging inter alin that the debtor was hopelessly insolvent. The debtor filed a cross petition under the first proviso of Section 75(s)(3) asking for a reappraisal of the land and fur the privilsge of redeeming at the reappraised value. Although previous decisions had indicated that an unqualified right to a public sale was a necessary creditor safeguard [Louistille Joint Stock Land Bank v. Radford, 295 U. S. 555 (1935); Wright v. Vinton Eranch of Mountain Trust Bank, 300 U. S. 40 (1937)], the Supreme Court lield that the debter must first be given the opportunity to redeem.

79. See Steinbergh, supra note 74, at 210. 
these errors are not to be repeated in the ensuing era of rising prices and farm values, a redetermination of appraisal methods is in order.

The basic principle of sound farm credit is that mortgage indebtedness must not exceed the debt-carrying capacity of the farm. ${ }^{80}$ It is the function of an appraisal to determine this capacity. While some indication is given by the normal value of the farm or its recovery value or its market value, the direct and appropriate attack on the problem is through an analysis of farm. income available for debt payments. The Farm Security Administration has successfully used this technique in administering its Tenant Purchase Program. ${ }^{81}$ Loans are made up to the capitalized value of the net farm income. ${ }^{82}$ A margin of error is allowed by capitalizing the net income at a slightly higher percentage than is actually required to pay interest and retire the loan within a given period..$^{83}$ No appraisal scheme can eliminate errors of judgment, but this method has the merit of focusing attention upon the definitive factor - the income of the farmer which may be used to pay interest and principal on his debt. In determining what this income actually is, questions of whether to base calculations upon AAA payments and acreage restrictions, ${ }^{84}$ what price levels to use in calculating prospective farm income, how much weight to give to personal characteristics of the borrower, and kindred problems will inevitably arise and errors may be made. The solution is to work toward greater precision in analysis. It is no answer to these problems to turn from income analysis to calculation of the normal value of the farm as determined by a vastly more complex series of indices. The use of the earning capacity standard of valuation would obviate considerations of the ratio which the loan should bear to the value of the farm

S0. See Yearbook of Agriculture (U. S. Dep't Agric. 1940) 752-54.

81. Authority for this program is contained in the Bankhead-Jones Farm Tentunt Act of 1937. 50 STAT. 522 (1937), 7 U. S. C. $\$ \$ 1000-06$ (1940). In three years of operation from 1937 to $1939,12,234$ tenant-purchase loans averaging $\$ 5,721$, were made. The popularity of the program is demonstrated by the fact that more than 20 applications have been filed for every loan which it has been possible to make. See REPoRT or trit: Administrator of the Farm Security Administration (1940) 12-13; Yenrdook of Agriculture (U. S. Dep't Agric. 1940) 898-901. For an explanation of the appraisal method used, see Tenant Purchase Appraisal Bulletin No. 1 (U. S. Farm Sec. Adm'n, 1941).

82. The net income is calculated by determining gross income expected from sales of crops and livestock under typical management based on the present ability of the farm to produce; from this gross income are deducted estimated expenses, including operating costs, depreciation on equipment, maintenance of buildings, taxes and insurance, estimated cash family living expense, and interest on operating capital. Sec Teltant Purchase Appraisal Bulletin No. 1 (U. S. Farm Sec. Adm'n, 1941) 5-8.

83. See id. at 6 .

84. In determining earning capacity under the Tenant Purchase Program, $\triangle A A$ acreage restrictions are uniformly used, but the question of whether to credit AAA payments is left to regional discretion because of differing conditions throughout the country. See id. at 9. 
as collateral security. ${ }^{85}$ It would eliminate the distinction which now exists between land bank loans and Land Bank Commissioner loans as the result of different collateral requirements, and a single credit agency could administer the loans on a uniform basis. ${ }^{.0}$

The Wheeler-Jones Bill of $1940^{87}$ and the current Eankhead-Fulmer Bill, 89 both directed toward a solution of farm credit problens, indicate that conflicting opinion on appraisal persists. The strength of the Wheeler Bill lies in its break with methods used in the past and its support of the earning capacity standard of valuation. The pending Bankhead-Fulmer Bill, however, reaffirms the traditional valuation standards which have resulted in the excessive mortgage indebtedness and insecurity of tenure now extant.

Refinancing and Scale-dozm of Excessize Mortgage Indebtedness. Any revision of the long-term credit system must provide means for a scale-down of present inflated mortgage indebtedness, and for refinancing of the borrower. It is important that mortgagees recognize and write off their losses promptly, instead of waiting until farms have deteriorated and the soil has been mined in a futile effort on the part of the farm-debtor to carry out the mortgage contract. ${ }^{89}$ Bankruptcy and moratorium laws designed to reduce excessive indebtedness or postpone the reckoning have demonstrated their inadequacy when unaccompanied by provisions for refinancing of the lorrower. ${ }^{90}$ Recognizing this, the Wheeler and Fulmer Bills combine a method of debt-adjustment with a program of refinancing of the delinquent borrower. They provide first for a determination by a debt-adjustment committee that the mortgage indebtedness is greater than the value of the farm. If this is established, the mortgagor may convey title to the land bank or the Federal Farm Mortgage Corporation; they in turn will release him from his mortgage obligations and permit him under a five-year lease to remain on the property and continue to farm. At the termination of the lease, he may repurchase the property at its appraised value and enter into a repurchase mortgage with the land bank.

However promising these proposals, they raise many problems. Selection of the debt-adjustment committee is of considerable importance. The committee should be experienced in farm mortgage problems and free from the influence of interested parties. While both bills rely heavily upon the national

85. With such factors as sale value, replacements costs, and per-acre values climinated from the appraisal scheme, conceptions of "50\% of the value of the land" and "20\% of the value of the improvements" become obsolete.

86. The extent to which these two lending procedures are identical is indieated in 1 C. C. H. 1941 Fed. Admin. Proc. at p. 13,185.

37. S. 3509, 76th Cong., 3d Sess. (1940); H. R. 8748, 76th Cong., 3d Sess. (1940).

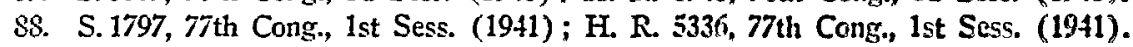

S9. See Hearings before Committec on Agriculture on H. R. s748, 76th Cong., 3d Sess. (1940) 255.

90. See supra p. 658-59. 
farm loan associations for this function, it would seem that the conciliation commissioners who administer Section 75 of the Bankruptcy Act might well be used. By this technique it would be possible to coordinate Frazier-Lemle bankruptcy proceedings with debt-adjustment and refinancing under the proposed legislation. ${ }^{91}$ This in itself would effect a needed simplification of procedures for distressed farmers.

More significant is the question of determining whether the mortgage indebtedness is greater than the value of the farm. The Wheeler Bill permits an adjustment of indebtedness if the farm-debtor establishes that his indebtedness is in excess of the productive value of the mortgaged farm or that the payments due on such indebtedness exceed the normal farm income available for such payments. Such a standard is far more constructive than that of the Fulmer Bill which states only that a farm-debtor will be entitled to an adjustment if he establishes that his indebtedness is greater than the value of his farm, without specifying how the farm value is to be determined. The stanclard of valuation sponsored in the Wheeler-Jones Bill is one which would have the desired effect of bringing mortgage indebtedness into line with the debt carrying capacity of the farm. The Bankheat-Fulmer Bill lacks both clarity and directness in this respect.

In the debt-adjustment procedure whereby the farm is conveyed to the land bank in exchange for a release of all mortgage indebtedness, the rights of third-party lienholders must be preserved. This is done in the Whecler and Fulmer Bills by authorizing the land bank or the Federal Firm Mortgage Corporation to assume the liens in exchange for bonds or cash before debt-adjustment takes place. While this procedure would obviate the legal problems arising from possible infringement of creditor interests, it would seem to be an unnecessary gratuity to the lienholders in the light of the Wright case, ${ }^{92}$ which gives the debtor's redemption privilege priority over the creditor's right to a public sale. ${ }^{93}$ This decision would seem to permit an evaluation of the farm property and all liens thereon by the debt-icljustment committee, after proper hearing of all parties. If the third-party lien is not superior to the land bank mortgage, and if the value of the property is less than the land bank mortgage, the thircl party would have no equity to be infringed, and would therefore suffer no injury by a write-off of the farmer's indebtedness. If his lien is superior to that of the land bank, at tender of the appraised value of the lien by the land bank to the lienholder should be sufficient to comply with the rights of the creditor as outlined in the Wright case.

91. It would be necessary in any event to provide for a stay in Frazicr-I.cmke proceedings while debt-adjustment and refinancing under the proposed legislation werc taking place.

92. 311 U. S. 273 (1940).

93. See note 78 supra. 
Any satisfactory debt-adjustment program must be cuupled with refinsulcing provisions for the debtor. Proper refinancing controls, morcwver, can be used to correlate the eredit system with uther agricultural program, in operation. $^{91}$ Thus, wastage clauses included in repurchase murtgages shuuld be broad enough to require the adoption of conservation practices. ${ }^{95}$ If the farm is too small to constitute an efficient productive unit, ur if additiunal improvements are needed to enahle a diligent family to opurate the farm successfully, refinancing arrangements should provide for these adjustment, in size and equipment. ${ }^{\text {Ot }}$ This technique has heen effectively used in the unitreorganization loans of the Farm Security Administration. ${ }^{\text {it }}$ Credit contruls may also be used to secure proper land-use adjustments.9s "The production goals set by the Department of Agriculture for the enstuing ytars call for increased production of certain commodities and for stable or decreasing yields of others. ${ }^{90}$ Credit extension can be directed tuward the achievement of these goals by discouraging increased farmer indebtedness fur the pruduction of non-essential commodities, and by making credit available fur changes in farm operations which will permit mure cumplete cuuptration with the program outlined. These techniques, combined with refinancing at low interest rates, and amortization of the luan uver a lung period of time, will do much to secure the stability of tenure which is a freretpuisite to intelligent farm management and long-range planning. ${ }^{100}$

Elimination of the Stock Subscription Reyuirmont.101 The furmur is the only borrower who is forced to become a stockhulder in the lending institu-

94. The importance of coordinating the credit system with wil conservation juoject. land-use adjustments and other agricultural programs is indicatcl ty the relithin-tip, between mortgage foreclosures and such factors as suil fertility, typs ui lanul, and $u$

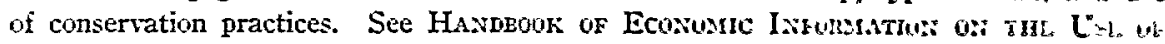
FARI CREDIT (U. S. Farm Credit Adm'n) 7-8.

95. See Johnson, Farm-Crcdit Policy as a Fachn in Suil (insiratitun (143y) $15 \mathrm{~J}$. Land \& P. U. Ecow. 377, 380.

96. See Yeareook of Agricultune (U. S. Depit Agric. 1140) 409.

97. See id. at $\$ 96$.

98. See Johnson, loc. cit. supra nute 95.

99. Increases in the products of dairy cows, hugs, and chithens are contumflatul, with possible decreases in oats, wheat, cotton, and tulacio. For a discussion of thise national goals for 1942, see 25 The Agricurturir. Situstun: (Bur. ui Agric. Iinon, C. S. Dep't Agric., Nov., 1941) 2.

100. Because of its indestructability and the curtainty of pernitual demant fi.r if

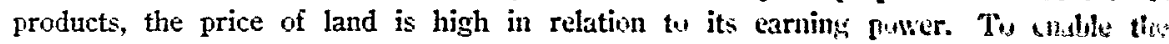
borrower to repay the loan, low interest rates and long-term amurtizating are a nees: it:

101. The Wheeler-Jones Bill advacated complete abandonment if this riguirsmbint. but the Bankhead-Fulmer Bill has attempted to work wut a compromics meanure whire s. instead of the $5 \%$ stock subscription, a membership fee of $2 \%$, of the burrewer's 1, , in would be charged. On a doctrinal level, it would seem that the uhigectiun; to the existing stock subseription requirement are equally valid when applicd t. stoh is mem* bership fee. 
tion as a condition of securing the loan. ${ }^{102}$ The requirement has not created the cooperative credit system which was intended; it has in fact operated as an additional $5 \%$ commission for the loan and has thus tended to keep the better risks out of the system. Whether the outstanding stock can be retired without impairing bondholders' security is problematical. The seeming intent of the Act is that this could be done, since the stock is not security for the land bank bonds. These bonds are secured by farm mortgages and Government bonds, ${ }^{103}$ and the stock is held by the land bank only as security for payment of the mortgage loan. ${ }^{104}$ It is specifically provided in Sections 7 and 8 of the Farm Loan Act, however, that the stock shall be retired upon full payment of the loan. This means that the mortgage is worth only $95 \%$ of its face value, and, therefore, that the bonds issued with the mortgages as security are $5 \%$ water. On this reasoning, retirement of the stock would merely establish the bonds at their true worth. Courts, however, seem to have rejected this interpretation of the Act. They have held that in case of foreclosure of the mortgage ${ }^{105}$ or insolvency of the farm loan association through which the loan was made ${ }^{106}$ the borrower is not entitled to a setoff for his stock. In adopting this view, they have argued that it was the evident purpose of the Act to make all borrowers liable for obligations of the farm loan association up to the amount of their stock subscription. $\Lambda$ ssuming that this argument is correct and that it justifies refusal to allow a set-off for the stock subscription when the association is insolvent, it provides no explanation for cases not involving the insolvency of the farm loan association, where the only question presented is whether a set-off for the borrower's stock should be allowed in a foreclosure proceeding. In view of the evident confusion of the law on this point, it might be necessary to provide for a substitution of collateral to the extent of the stock retired, or for an outright guarantee of the land bank bonds. Either of these methods would eliminate any question of injury to the bondholders by retirement of the stock.

102. The requirement is customary among Government agricultural lending agencies, such as production credit associations [48 Stat. 261 (1933), 12 U. S. C. \$1131g (1940)], and banks for cooperatives [48 STAT. 264 (1933), 12 U. S. C. $\$ 1134 d$ (1940)].

103. Section 13 (subd. third).

104. Section 7.

105. Federal Land Bank of Beekley v. Warner, 42 Ariz. 201, 23 P. (2d) 563 (1933), rev'd on other grounds, 292 U. S. 53 (1934). The rationale of the court was that an essential to the right of set-off or counterclaim is that the debts be between the same persons, and that since the borrower from a farm loan association is a stockholder in the association and not in the land bank, no set-off was admissible. Considering the spurious character of the farm loan associations as independent agencies, this decision is at best one on form and not substance.

106. Knox National Farm Loan Association v. Phillips, 300 U. S. 194 (1937); Western Clay National Farm Loan Association v. Lilly, 189 Ark. 1004, 76 S. W. (2d) 55 (1934); Byrne v. Federal Land Bank of St. Paul, 61 N. D. 265,237 N. W. 797 (1931). 
Guarantec of Land Bank Bonds.107 Land bank bonds backed by a straight Government guarantee could be issued with staggered maturities at an average rate of interest of approximately $2 \%,{ }^{108}$ contrasted with the present rates of from $3 \%$ to $4 \%$ for unguaranteed bonds. It is necessary to stagger the maturities, since long-term loans cannot safely be made when loan funds are obtained only on a short-term basis. If $1,2, \%$ of each loan were charged for administrative expenses and losses, a figure which should be adequate on the basis of past experience, ${ }^{109}$ the land bank could make long-term loans for approximately $3 \mathrm{r} / 2 \%$. This is the rate now jaid by borrowers, lut the guarantee would make it possible to discontinue the $\$ 36,500,000$ annual interest subsidy at present required to maintain it. By fixing the loan rate at the cost of money to the land bank, plus $11 / 2 \%$ for expenses, the system would be self-sustaining, and the loan rate would automatically reflect changes in the cost of money. Moreover, the use of the bond guarantee would make possible a gradual liquidation of the Federal Farm MLortgage Corporation. Its function in the past has been to purchase unguaranteed land bank bonds and to sell its own guaranteed bonds on the open market.110 This circuitous arrangement by which the land banks obtained funds would be unnecessary, and the Mortgage Corporation could gradually liquidate as its bonds were called in. The liquidation would accomplish a needed simplification of credit agencies. Land Bank Commissioner loans now made by the Corpuration are in all essentials similar to those of the land banks, and in fact the land bank organization is used in making them. ${ }^{111}$ This fact militates strongly in favor of establishing the land banks as a unified govermmental agency for handling all long-term loans to agriculture.

107. An outright guarantee of the bonds was proposed in the Wheler-Iunes Bill; the Bankhead-Fulmer Bill merely authorizes the Federal Farm Mrortgage Corn'mration to purchase the bonds whenever the interest rate exceeds by more than if if $1{ }^{\circ} \mathrm{c}$, the rate on Corporation bonds. This presents the same tyne of $b$ unus to investurs which has operated in the past. See supra p. 654-55.

108. See Hearings before Committee on Agricul/ure on $H$. $R$. dits, 7oth Cong, 3d Sess. (1940) 132, 141.

109. During 23 years of existence, the expense of uperation was . $545_{0}:$ of each loan, losses, .27\%, estimated losses and reserves for losses, .28\%, a total of $1.09 \%$. Sce Hearings on S. 3509, 76th Cong., 3d Sess. (1940) 211. The actual margin between han rates and bond rates has been $1.56 \%$ including reserves for lusses not yet realized, and undivided profits. See id. at 15.

110. See note 50 stipra.

111. See 1 C. C. H. 1941 Fed. Admin. Proc. at p. 13,185 . 